The Triumph of Provocation 
This page intentionally left blank 


\section{The Triumph of Provocation}

Józef Mackiewicz

Translation by Jerzy Hauptmann,

S. D. Lukac, and Martin Dewhirst

Foreword by Jeremy Black

Yale University Press

New Haven \& London 
Published with assistance from the foundation established in memory of Henry Weldon Barnes of the Class of I882, Yale College.

Copyright (C) 2009 by Nina Karsov. All rights reserved. This book may not be reproduced, in whole or in part, including illustrations, in any form (beyond that copying permitted by Sections I07 and I08 of the U.S. Copyright Law and except by reviewers for the public press), without written permission from the publishers.

First published as Zwycięstwo prowokacji, copyright @ 1962 by Józef Mackiewicz. Set in Garamond and Stone Sans types by The Composing Room of Michigan, Inc. Printed in the United States of America.

Library of Congress Cataloging-in-Publication Data

Mackiewicz, Józef.

[Zwycięstwo prowokacji. English]

The triumph of provocation / Józef Mackiewicz; translation by Jerzy Hauptmann, S.D. Lukac, and Martin Dewhirst ; foreword by Jeremy Black.

p. cm.

First published in Polish in 1962 under title Zwycięstwo prowokacji.

Includes bibliographical references.

ISBN 978-0-300-I4569-4 (cloth : alk. paper) I. Poland-Relations-Soviet

Union. 2. Soviet Union-Relations-Poland. 3. Communism-Poland.

4. Poland-Politics and government-1945-1980. 5. Mackiewicz, Józef. I. Title.

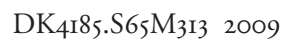

$327.438047-\mathrm{dc} 22$

2008051565

A catalogue record for this book is available from the British Library.

This paper meets the requirements of ANSI/NISO Z39-48-1992 (Permanence of Paper).

IO 98765432 I

Extracts from Norman Davies, God's Playground: A History of Poland, vol. 2 (Oxford: Clarendon Press, 198I) are reprinted by permission of Oxford University Press and Columbia University Press. The extract from Kyril FitzLyon and Tatiana Browning, Before the Revolution. A View of Russia Under the Last Tsar (London: Allen Lane, 1977) is reprinted by permission of Kyril FitzLyon. Extracts from Jan T. Gross, Revolution from Abroad: The Soviet Conquest of Poland' Western Ukraine and Western Belorussia (Princeton: Princeton University Press, 1988) are reprinted by permission of the publisher. Extracts from “To the New Moon” by Salvatore Quasimodo are taken from Complete Poems, trans. Jack Bevan (London: Anvil Press Poetry, 1983) and are reprinted by permission of the publisher. Extracts from Alfred Erich Senn, The Great Powers, Lithuania and the Vilna Question 1920-1928 (Leiden: E. J. Brill, 1966) are reprinted by permission of Alfred E. Senn. 